\title{
Development of Integrated Disease Control Measures for the Valorisation of Traditional Crops in Southern Italy: The Case Study of Fagioli di Sarconi
}

\author{
Pietro Lo Cantore, Annalisa Giorgio, Bruno Campion, \\ and Nicola Sante Iacobellis
}

\begin{abstract}
The cultivation of Fagioli di Sarconi $(F S)$, a pool of traditional varieties protected with the mark PGI (Protected Geographical Indication) cultivated in the National Park of Agri Valley in Basilicata (southern Italy), is limited by common bacterial blight (CBB), caused by the seed-borne bacterium Xanthomonas axonopodis pv. phaseoli (Xap) and X. a. pv. phaseoli var. fuscans (Xapf), whose control is difficult because of the lack of safe bactericides. Hence, studies were undertaken to assess the susceptibility/tolerance of selected varieties toward the pathogens and to develop eco-compatible measures for the disease management. Five $F S$ varieties showed a differential response to inoculations with virulent strains of the pathogens, and hence, two tolerant cultivars were selected for the introgression of $\mathrm{CBB}$ resistance characters. Among the main active components of some essential oils, eugenol determined a highly significant reduction of Xap density on bean seeds, though at the higher dosage, the seed germination reduction was observed. These data indicate eugenol as potentially useful for bean seed disinfection from Xapf, though further studies appear necessary. Among 162 bacterial isolates from bean rhizosphere, six caused a clear reduction of lesions size ranging from 30 to $66 \%$ suggesting that induced systemic resistance may be involved in that feature.
\end{abstract}

\footnotetext{
P. Lo Cantore $(\square) \bullet$ A. Giorgio $\bullet$ N.S. Iacobellis $(\square)$

Scuola di Scienze Agrarie, Forestali, Alimentari ed Ambientali, Università degli Studi della Basilicata, via Ateneo Lucano 10, 85100 Potenza, Italy e-mail: pietrolocantore@tiscali.it; pietro.locantore@unibas.it; annalisa_grg@yahoo.it; nicola. iacobellis@unibas.it

B. Campion

CRA, Unità di Ricerca per l'Orticoltura, Montanaso Lombardo, LO, Italy

e-mail: bruno.campion@entecra.it
} 


\section{Introduction}

Common bean (Phaseolus vulgaris L.) is one of the most important legumes due to its commercial value and its high content of quality carbohydrates, proteins, minerals and vitamins. FAO data (FAO Statistics Division 2014) on bean production in Europe indicate that in 2012, Belarus, Spain and Italy were the main bean producers. In fact, bean production was 227.259 $\mathrm{t}$ in Belarus (only for dry beans), $175.300 \mathrm{t}$ in Spain (165.400 for string and 9.900 for dry beans) and $145.933 \mathrm{t}$ in Italy (134.124 for string and 11.809 for dry beans). In Italy, besides the commercial cultivars, there is an abundance of traditional varieties with unique nutritional features and for which there is a traditional market (Dinelli et al. 2006). This is the case of the Fagioli di Sarconi $(F S)$, a pool of traditional high-value traditional varieties, selected from various landraces (Masi et al. 1999; Piergiovanni et al. 2000) and protected by the European Union (Reg. CEE No. 1263/96) with the mark PGI (Protected Geographical Indication).

FS are cultivated in the National Park of the Agri Valley in Basilicata (southern Italy) for dry seed production (Brandi et al. 1998). The germplasm, preserved on farm by the Consorzio di Tutela dei Fagioli di Sarconi, has been extensively characterised for its biochemical and nutriceutical traits (Piergiovanni et al. 2000; Lioi et al. 2005; Dinelli et al. 2006) but nothing is known about its response to diseases. As a matter of fact, the above varieties are plagued by the common bacterial blight (CBB), caused by Xanthomonas axonopodis pv. phaseoli (Smith) Dye (Xap) and X. a. pv. phaseoli var. fuscans (Xapf) (Vauterin et al. 1995), and since 2002, there have been several severe outbreaks of this disease. Bean field surveys in 2001-2002 showed that at the end of the production cycle, nearly $100 \%$ of the plants were infected, with the consequent heavy crop loss. The disease is endemic and some evidences indicate its introduction by long time. The use of bean seed grown on farm, possibly infected and/or contaminated by the pathogens, the limited copper sprays and the use of overhead irrigation have facilitated the dissemination of the pathogen and the maintenance of a high level of the inoculum potential. Year by year, bacterial disease outbreaks have been greatly facilitated by the particular climatic conditions which, as observed in the above years, were characterised by heavy rains during the periods from July to September (Lo Cantore et al. 2004a). CBB pathogens infect all the plant organs and the disease development is favoured by warm temperature $\left(25-35^{\circ} \mathrm{C}\right)$ and humid conditions (Gilbertson and Maxwell 1992; Saettler 1989). CBB symptoms on foliage are water-soaked spots that enlarge forming dark brown necrotic lesions often surrounded by chlorotic zones. Infected pods exhibit circular water-soaked areas that turn to reddish-brown lesions. Pod infection often causes discoloration, shrivelling and bacterial contamination/infection of seeds though in some cases, they may appear healthy (Saettler 1989). 
The causal agents of CBB, Xap and Xapf, are distinguished from each other only because Xapf produces a brown pigment when grown on some specific agar media (Schaad et al. 2001). Nevertheless, there is considerable genetic diversity between Xap and Xapf (Chan and Goodwin 1999; Mkandawire et al. 2004; López et al. 2006; Mahuku et al. 2006), as recent AFLP analyses have confirmed (Lo Cantore and Iacobellis 2007; Alavi et al. 2008; Lo Cantore et al. 2010b). For that, a revision of the two pathogens classification has been proposed (Schaad et al. 2005, 2006).

Dissemination in the field is mainly determined by wind-driven rain and overhead irrigation, but also by insects, field workers and contaminated equipment (Gilbertson and Maxwell 1992; Saettler 1989), which may play an important role. Common bacterial blight is the major seed-borne disease of common bean worldwide (Tarlan et al. 2001; Miklas et al. 2003), and the best way to manage CBB includes the use of pathogen-free seed (Zanatta et al. 2007). In order to control $\mathrm{CBB}$, the use of bean cultivars with genetic tolerance/resistance to the disease is the most practical method (Coyne and Schuster 1974; Yoshii et al. 1978) though the availability of CBB-resistant cultivars is limited. In most of the cases, the resistance/tolerance of traditional varieties to CBB is unknown. This is the case of $F S$ varieties. Furthermore, pathogen-free seed is a prerequisite for a healthy crop, but to date no efficient disinfection method is available (Lo Cantore et al. 2009). Antibiotics, in fact, are actually restricted or forbidden in the agricultural practices in many countries (McManus et al. 2002) and the use of copper compounds, because of their general toxicity and impact on the environment, is constrained in Europe (EU rule no. 473/2002). Furthermore, chemical disinfectants such as chlorine, inorganic acids, organic acids and heat treatments have been used for disinfection of potentially contaminated seeds surface or to cure infected seeds, but seed devitalisation has been reported (Claflin 2003).

The above consideration prompts the need to assess, first, the response of the selected $F S$ bean varieties to $\mathrm{CBB}$ with the final aims to select resistant/tolerant traditional varieties and to introgress tolerance/resistance characters into the $F S$ varieties of interest. Moreover, of interest was the development of alternative methods for the control of $\mathrm{CBB}$ to be used in integrated crop management as well as in bio-organic agriculture. Several studies have pointed out the possibility to use essential oils and/or their components in medical and plant pathology as well as in the food industry for the control of microorganisms pathogenic to consumers and/or responsible for food spoilage (Seow et al. 2014). Nevertheless, most of the studies are mainly focused on the in vitro assessment of the antimicrobial activity (Si et al. 2006; Terzi et al. 2007), and the exploitation of essential oils for the control of plant diseases is still in its infancy (Tinivella et al. 2009; Kotan et al. 2010). Another opportunity for plant defence towards diseases is the use of beneficial bacteria inhabiting plant rhizosphere. In several works, it was demonstrated that some bacteria belonging to Pseudomonas and Bacillus genera are able to provide different mechanisms (direct or plant mediated) for suppressing plant diseases (Saharan and Nehra 2011). 
In this chapter, we report some of the results obtained in studies aimed to develop methods for integrated control of CBB.

\section{Response of Fagioli di Sarconi Varieties to CBB}

The objective of the present work was to evaluate the response to CBB of five traditional bean varieties (Tondino bianco, Verdolino, Cannellino, Tabacchino and Ciuoto) of the FS variety pool, in comparison to four available resistant bean breeding lines (VAX-4, USDK-CBB-15, ABC-Wiehing and USCR-CBB-20) (Singh et al. 2001; Miklas et al. 2006, 2011; Mutlu et al. 2008). Aliquots of bacterial suspensions of the highly virulent Xap and Xapf strains were inoculated into the first trifoliate mesophyll of bean plants (Lo Cantore et al. 2010a).

The traditional varieties Tondino bianco, Cannellino, Verdolino, Ciuoto and Tabacchino showed the typical CBB symptoms, and, in particular, at the inoculation sites, tiny water-soaked lesions 14 days after inoculation which then expanded and turned into necrotic spots surrounded by chlorotic halos were observed (see Fig. 1a, c). As expected, necrotic lesions of the hypersensitive reaction were observed on the CBB-resistant breeding lines (see Fig. 1b, c).

Twenty-eight days after inoculation, the $F S$ varieties statistically differed in their susceptibility depending on the pathogen strain used (see Fig. 2). Indeed, while strain USB749 (ICMP14929) of Xapf caused on Tondino bianco, Cannellino and Verdolino lesions significantly larger $(P<0.0001$; LSD.05 $=5.14 \mathrm{~mm})$ than those ones on cv. Ciuoto and Tabacchino (see Fig. 2a), Xap USB771 (ICMP14932) caused lesions on Tondino bianco and Tabacchino significantly larger $(P<0.001$; LSD.05 $=1.82 \mathrm{~mm}$ ) than those on Verdolino, Ciuoto and Cannellino (see Fig. 2b). The lesions on Ciuoto and Cannellino did not differ significantly from the lesions



Fig. 1 Symptoms on the traditional variety Verdolino (a-c) of Fagioli di Sarconi and hypersensitive necrotic lesions on the CBB-resistant breeding line ABC-Wiehing (b-d) 21 days after syringe infiltration with $10^{8} \mathrm{CFU} \mathrm{ml^{-1 }}$ suspensions of the highly virulent strain USB749 (ICMP14929) of Xanthomonas axonopodis pv. phaseoli var. fuscans (a-b) and of strain USB771 (ICMP14932) of X. a. pv. phaseoli (c-d). Adapted with permission from Lo Cantore P, Figliuolo G, Iacobellis NS (2010) Response of traditional cultivars of Fagioli di Sarconi beans to artificial inoculation with common bacterial blight agents. Phytopathol Mediterr 49:89-94. Copyright 2010 Firenze University Press 

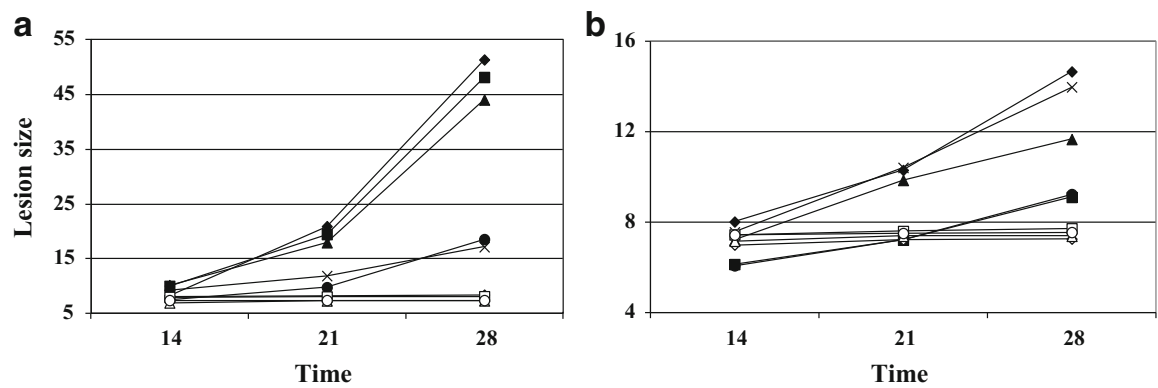

$$
\begin{aligned}
& \rightarrow \text { Tondino bianco } \rightarrow \text { Cannellino } \rightarrow \text { Verdolino } \rightarrow \text { Ciuoto } \rightarrow \text { Tabacchino } \\
& \multimap \text { USCR-CBB-20 } \neg-\text { USDK-CBB-15 } \neg \text { Vax } 4 \rightarrow \text { ABC Wiehing }
\end{aligned}
$$

Fig. 2 Response given by the traditional bean varieties of the Fagioli di Sarconi and by CBBresistant breeding lines 28 days after syringe infiltration of $10^{8} \mathrm{CFU} \mathrm{m}{ }^{-1}$ suspensions of the highly virulent strain USB749 (ICMP14929) of Xanthomonas axonopodis pv. phaseoli var. fuscans (a) and of strain USB771 (ICMP14932) of X. a. pv. phaseoli (b). Adapted with permission from Lo Cantore P, Figliuolo G, Iacobellis NS (2010) Response of traditional cultivars of Fagioli di Sarconi beans to artificial inoculation with common bacterial blight agents. Phytopathol Mediterr 49:89-94. Copyright 2010 Firenze University Press

on the breeding lines USDK-CBB-15, ABC-Wiehing and VAX-4, but they significantly differed from those on USCR-CBB-20 (see Fig. 2b).

In conclusion, the findings that the varieties Ciuoto, Tabacchino and Cannellino appeared to be less susceptible or tolerant to $\mathrm{CBB}$ are positive since it is well established that the use of pathogen-tolerant germplasm, rather than resistant one, is advisable in order to avoid the selection of the pathogen population overcoming the resistance. The above varieties, apart from their agronomic, biochemical and nutriceutical traits, appear good candidates for the introgression of CBB resistance characters in a breeding programme.

The results further suggest that the inoculation procedure is suitable to evaluate the susceptibility/tolerance and the resistance of bean cultivars and/or breeding lines. However, the response of the traditional bean varieties to CBB pathogens inoculation needs to be further confirmed by using different plant parts (i.e. pods) since the degree of resistance/susceptibility of Phaseolus spp. depends on the plant organ (Aggour et al. 1989; Rodrigues et al. 1999; Marquez et al. 2007).

The development of new bean breeding lines genetically resistant to Xapf was another aim of this work. The selection applied to these breeding lines should tend to combine, in their genetic background, the gene of resistance and all agronomic and nutriceutical traits present in the old varieties. The bean traditional varieties Tabacchino and Ciuoto, and bean breeding lines VAX-4 and USCR-CBB-20 carrying the resistance to Xaf (Singh et al. 2001; Miklas et al. 2011), were used in the breeding plan.

Numerous qCiuoto x USCR-CBB-20へ, qCiuoto x VAX-4ð, qTabacchino

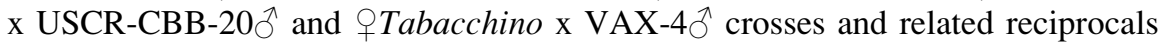
were made in greenhouse. All $\mathrm{F}_{1}$ plants were grown in the field until the production 
of eight groups of $\mathrm{F}_{2}$ seed progenies. $\mathrm{F}_{3}$ seeds obtained from $\mathrm{F}_{2}$ plants selected for Xapf resistance were sown in the field and related plants submitted to agronomic selection/evaluation. The choice of the best single plants was based on production capacity, plant hardness and health, and pod and seed quality. Only three types (groups) of crosses, out of the eight performed (qCiuoto x VAX-4 ${ }^{\lambda}$, , Tabacchino

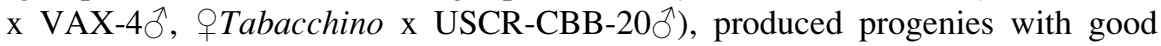
plant and seed traits. The seed progenies are at $\mathrm{F}_{4}$ generation level.

\section{Fagioli di Sarconi Seed Disinfection}

Our previous studies showed the antibacterial activity of coriander, caraway and cumin essential oils towards 29 bacterial pathogens of plants, including strains of Xap and Xapf (Iacobellis et al. 2005; Lo Cantore et al. 2004b). The objective of this study was to evaluate the in vitro antibacterial activity of the 19 main components of the above essential oils and to assess their potential use for bean seed disinfection. In disc diffusion assay (Lo Cantore et al. 2009), terpenoids and phenylpropanoids, having phenol and alcohol functionalities, showed a high bactericidal activity, inhibiting the growth of all bacterial strains used in this study, whereas a lower activity was shown by monoterpenes containing ketone, aldehyde and ester functionalities and the phenylpropanoids anethol. Monoterpenoids and sesquiterpenoid caryophyllene showed a lower activity and only on a limited number of the target bacteria. Based on the above results, eugenol was chosen in order to evaluate its disinfecting effects on the $F S$ variety Ciuoto seeds artificially contaminated with Xapf (Lo Cantore et al. 2009). Eugenol seed treatments (1, 2, 4 and $\left.8 \mathrm{mg} \mathrm{ml}^{-1}\right)$ caused a statistically significant reduction $(P<0.0001)$ of the bacterial population on bean seeds relative to the control sample (see Fig. 3). Assays with different bacterial densities bearing seeds and treatments with $4 \mathrm{mg} \mathrm{ml}^{-1}$ eugenol emulsions confirmed the higher efficiency of this essential oil to reduce bacterial population densities on bean seed surface when compared to the tetracycline treatments at a comparable MIQ value $\left(100 \mu \mathrm{g} \mathrm{ml}^{-1}\right)$. However, eugenol emulsions at concentration equal or superior to $2 \mathrm{mg} \mathrm{ml}^{-1}$ caused a significant reduction of the seed germination compared to the control (see Fig. 4).

In conclusion, essential oils and/or pure components appear to be good bactericides as alternatives to antibiotics for the control of seed-borne plant pathogen bacteria.

The use of eugenol instead of complex oil mixtures may be desirable since this avoid the variability of essential oils and, furthermore, the possible toxicity of other no bactericide essential oil components. The reduction of bean seed germination after treatments with eugenol was already reported (Asplund 1968; Reynolds 1987; Oosterhaven et al. 1995), but the limited effect on bean seed germination observed at eugenol lower concentrations indicates a starting point for a possible amelioration of the disinfectant formulation and disinfection method. 


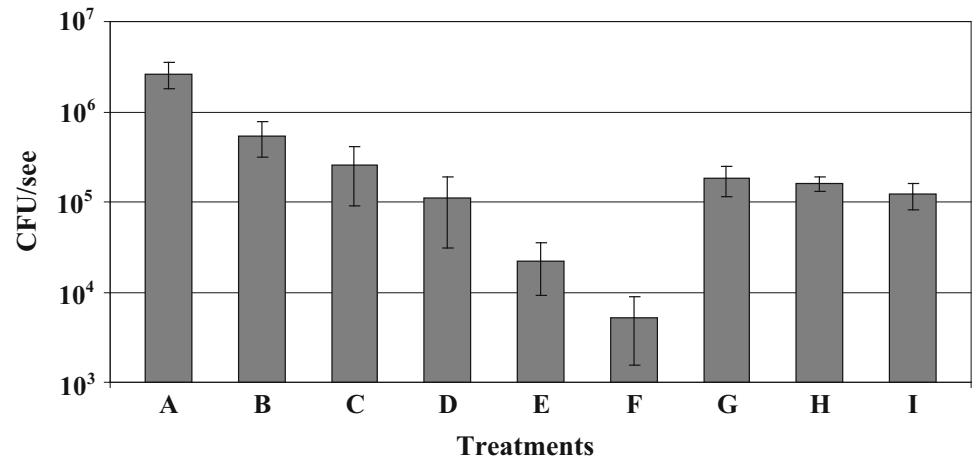

Fig. 3 Bacterial populations of the spontaneous mutant resistant to rifampicin of strain ICMP239 of Xanthomonas campestris pv. phaseoli var. fuscans on bean seeds bearing about $2.6 \times 10^{6} \mathrm{CFU}$ per seed after different treatments $(\mathrm{A}=$ control, no treated seeds; $\mathrm{B}=$ control, seeds treated with water containing $0.01 \%$ Tween $20 ; \mathrm{C}, \mathrm{D}, \mathrm{E}$ and $\mathrm{F}=$ seeds treated with $1,2,4$ and $8 \mathrm{mg} \mathrm{ml}^{-1}$ of eugenol in water emulsions containing $0.01 \%$ Tween 20 , respectively; $\mathrm{G}, \mathrm{H}$ and $\mathrm{I}=$ seeds treated with 50, 100 and $200 \mu \mathrm{g} \mathrm{ml}^{-1}$ tetracycline solutions containing $0.01 \%$ Tween 20 , respectively). Bars on the columns correspond to the standard error of the mean. Means of bacterial populations on bean seeds after eugenol and tetracycline treatments, evaluated by the $t$-test in comparison with the means of bacterial populations on bean seeds of the controls A and B, are statistically different $(P \leq 0.002)$. Adapted with permission from 'Lo Cantore $P$, Shanmungaiah V, Iacobellis NS (2009) Antibacterial activity of essential oil components and their potential use in seed disinfection. J Agric Food Chem 57:9454-9461'. Copyright 2009 American Chemical Society

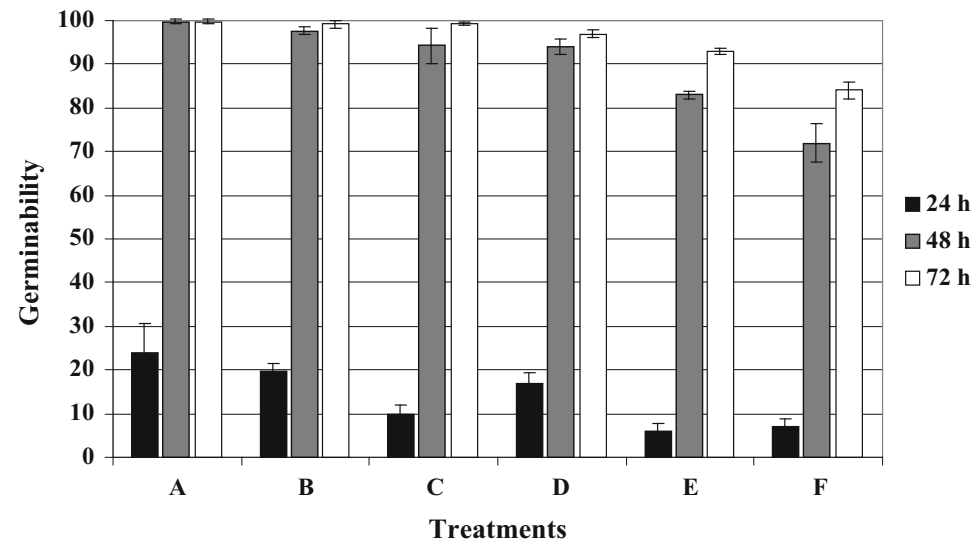

Fig. 4 Germination of bean seeds after different treatments with eugenol $(\mathrm{A}=$ control, no treated seeds; $\mathrm{B}=$ control, seeds treated with water containing $0.01 \%$ Tween $20 ; \mathrm{C}, \mathrm{D}, \mathrm{E}$ and $\mathrm{F}=$ seeds treated with $1,2,4$ and $8 \mathrm{mg} \mathrm{ml}^{-1}$ of eugenol in water containing $0.01 \%$ Tween 20 , respectively). Bars on the columns correspond to the standard error of the mean. The $t$-test of data at $72 \mathrm{~h}$ showed that means of geminated seeds after eugenol treatments $\left(8,4\right.$ and $\left.2 \mathrm{mg} \mathrm{ml}^{-1}\right)$, in comparison with the controls $(\mathrm{A}$ and $\mathrm{B})$, are statistically different $(P<0.0001)$ and $(P<0.02)$, respectively. No statistical differences were observed in the case of treatments with $1 \mathrm{mg} \mathrm{ml}^{-1}$ eugenol emulsion. Adapted with permission from 'Lo Cantore P, Shanmungaiah V, Iacobellis NS (2009) Antibacterial activity of essential oil components and their potential use in seed disinfection. J Agric Food Chem 57:9454-9461'. Copyright 2009 American Chemical Society 


\section{Beneficial Rhizobacteria as Biocontrol Agents of CBB in Fagioli di Sarconi}

Rhizobacteria are microorganisms living plant rhizosphere and some of them are able to reduce plant diseases by several direct mechanisms (i.e. niche exclusion, competition for nutrients, siderophore-mediated competition for iron, antibiosis and production of extracellular hydrolytic enzymes) (Martinez-Viveros et al. 2010) or indirectly by stimulating the basal plant defence mechanisms, phenomenon called induced systemic resistance (ISR) (Van Loon 2007).

As already discussed, CBB is difficult to manage via the conventional methods. In an integrated view of CBB control, the biological one based on the use of antagonist rhizobacteria may represent another opportunity.

The aim of this study was to evaluate the potential of selected rhizobacteria isolated from bean rhizosphere to protect plants against $\mathrm{CBB}$ in in vitro and greenhouse conditions. In total, 162 rhizobacteria were isolated from bean rhizosphere in the National Park of Agri Valley (Basilicata, southern Italy) and screened in dual-plate assays for their potential capacity to antagonise the growth of CBB pathogens. Sixty out of 162 rhizobacteria inhibited in vitro the growth of Xap, and 38 of these were also active against Xapf; thus, they were assayed for hydrolytic enzyme production. Subsequently, they were evaluated, when applied to seeds before sowing, for their possible effect on Xapf-plant interactions. The results of these assays have allowed selecting six bacterial isolates that were capable to protect, with diverse efficacy, bean plants artificially inoculated, in vitro and greenhouse assays, with a highly virulent strain of the mentioned pathogen. Indeed, the reduction of lesions size ranged from about 25 to $55 \%$ in vitro and from about 35 to $65 \%$ in greenhouse experiments compared to the controls (see Fig. 5). The six selected isolates were identified by partial PCR amplification of $16 \mathrm{~S}$ rDNA as three strains of Pseudomonas brassicacearum subsp. brassicacearum, two strains of


Fig. 5 Symptoms of common bacterial blight on trifoliate leaves developed 21 days after syringe without needle inoculation with suspension $\left(10^{8} \mathrm{CFU} \mathrm{ml}^{-1}\right)$ of strain USB749 (ICPPM 14929) of Xanthomonas axonopodis pv. phaseoli var. fuscans. Comparison between bean plants obtained from not bacterised (left) and bacterised seeds (right). In (a) and (b), bean plants from seeds are

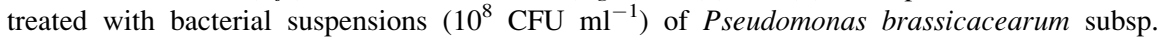
brassicacearum strains (USB2101, USB2102) 
P. putida and one of Bacillus megaterium. The antagonist bacteria were then further characterised for phosphate solubilisation (Nautiyal 1999), nitrogen fixing activity (San Yu et al. 2011), production of indole compounds (Gordon and Weber 1951) and siderophores (Schwyn and Neilands 1987), haemolytic capacity (Lo Cantore et al. 2006) and production of ammonia (Cappuccino and Sherman 2010) and of hydrogen cyanide (Lorck 1948). Finally, bacteria were evaluated for adaptability to salinity, $\mathrm{pH}$ and temperature gradients (Giorgio 2014; Giorgio et al. 2013).

The mechanisms underlying bean plant protection are not completely understood so far. At the base of the pathogen control exerted by the six mentioned bacteria, some likely explanations exist. In the pathogenicity assays, the rhizobacteria and the challenging pathogen were apparently spatially separated and this may suggest that the observed effect may result from the activation in bean plants of induced systemic resistance (ISR) (Van Loon 2007). The ability to trigger ISR by some of the above rhizobacteria has been ascertained in further parallel studies in the pathosystem Arabidopsis thaliana-X. campestris pv. amoriaceae (Giorgio 2014; Giorgio et al. 2013). Molecular studies leading to determine the occurrence of ISR in beanXapf pathosystem are in progress. However, a direct effect of rhizobacteria on the pathogen at the infection site cannot be excluded since it has been reported that bacteria applied to soil or on seeds colonise rhizosphere and then may move up to the phylloplane (Nautiyal et al. 2002) or to behave as either facultative or opportunistic endophytes (Hardoim et al. 2008). Some characters shown by rhizobacteria under study may be the responsible of the possible direct antagonism exerted on the pathogens. In fact, the haemolytic activity shown by these bacteria may depend on the production of antimicrobial substances affecting biological membranes which is a quite common feature in plant-associatedPseudomonas spp. and Bacillus spp. (Ongena and Jacques 2008; Raaijmakers and Mazzola 2012). Furthermore, of great interest is the fact that strains of $P$. $b$. subsp. brassicacearum produce $\mathrm{HCN}$ reported as inhibitor of cytochrome C oxidase in the respiratory chain (Knowles 1976) and binding metalloenzymes (Blumer and Haas 2000) determining deleterious effect in microorganisms inhabiting the same ecological niche and nonproducers of HCN. On the other side, $P$. putida strains appeared to produce ammonia that accomplishes several biological roles and, in particular, its toxicity is well known (Weise et al. 2013). The six antagonistic rhizobacteria showed also desirable plant growthpromoting ability since they can supply inorganic phosphate to plants (Schachtman et al. 1998) via phosphatase activity which leads to the production of organic acids that decrease soil pH (Rashid et al. 2004), so that this may limit some soilborne phytopathogenic organisms, as demonstrated in the case of $P$. ultimum and $F$. oxysporum (Alhussaen 2012). Moreover, in this regard, important is the fact that the six rhizobacteria produce also indole compounds that promote bacterial environmental adaptation during stress conditions such as UV, salt and acidity (Bianco et al. 2006). Finally, their siderophore production may contribute to plant growth-promoting activity by depriving pathogens of iron accomplishing, in this way, their antagonistic activity (Kloepper et al. 1980). In conclusion, the fact that numerous mechanisms may be involved in leading to the observed effects makes worthwhile a deeper investigation on the system considered. 


\section{Concluding Remarks}

In conclusion, the findings that the Fagioli di Sarconi traditional varieties Ciuoto, Tabacchino and Cannellino appeared to be less susceptible or tolerant to CBB are positive since it is well established that the use of pathogen-tolerant germplasm, rather than resistant one, is advisable in order to avoid the selection of the pathogen population, leading to the resistance being overcome. The introgression and stabilisation of $\mathrm{CBB}$ resistance characters into some of the above tolerant traditional varieties, in the breeding programme still in progress, may bring about to highly agronomic and nutriceutical values varieties with potential economic impact.

Essential oils and/or pure components such as eugenol appear to be good bactericides as alternatives to antibiotics for the sanitation of bean seeds from CBB pathogens as well as for the control of other seed-borne plant bacterial pathogens. However, studies either on formulations or on the application method of eugenol appear necessary to avoid undesirable toxic effect on seeds and plantlets.

Lastly, of highly value is the finding that strains of Pseudomonas brassicacearum subsp. brassicacearum, P. putida and Bacillus megaterium, isolated from bean rhizosphere, are capable of protecting bean plants artificially inoculated with the CBB pathogen. Also in these cases, further studies appear necessary to transfer these potential antagonists in the agriculture practices.

Acknowledgements This research was in part supported by the Ministry of Agricultural Alimentary and Forest Politics (project PROM, C.I.P.E. Resolution 17/2003). Dr. Phillip Miklas, of the Vegetable and Forage Crops Research Laboratory, USDA, WA, USA, and the Consorzio di Tutela dei Fagioli di Sarconi are acknowledged for the generous supply of CBB-resistant breeding lines and traditional cultivar seed lots.

Open Access This chapter is distributed under the terms of the Creative Commons Attribution Noncommercial License, which permits any noncommercial use, distribution, and reproduction in any medium, provided the original author(s) and source are credited.

\section{References}

Aggour AR, Coyne DP, Vidaver A (1989) Comparison of leaf and pod disease reaction of beans (Phaseolus vulgaris L.) inoculated by different methods with strains of Xanthomonas campestris pv. phaseoli (Smith) Dye. Euphytica 43:143-152. doi:10.1007/BF00037907

Alavi SM, Sanjari S, Durand F et al (2008) Assessment of the genetic diversity of Xanthomonas axonopodis pv. phaseoli and Xanthomonas fuscans subsp. fuscans as a basis to identify putative pathogenicity genes and a type III secretion system of the SPI-1 family by multiple suppression subtractive hybridizations. Appl Environ Microbiol 74:3295-3301. doi:10.1128/ AEM.02507-07

Alhussaen KM (2012) Effect of soil acidity on diseases caused by Pythium ultimum and Fusarium oxysporum on tomato plants. J Biol Sci 12:416-420. doi:10.3923/jbs.2012.416.420

Asplund O (1968) Monoterpenes: relationship between structure and inhibition of germination. Phytochemistry 7:1995-1997. doi:10.1016/S0031-9422(00)90758-1 
Bianco C, Imperlini E, Calogero R et al (2006) Indole-3-acetic acid improves Escherichia coli's defences to stress. Arch Microbiol 185:373-382. doi:10.1007/s00203-006-0103-y

Blumer C, Haas D (2000) Mechanism, regulation, and ecological role of bacterial cyanide biosynthesis. Arch Microbiol 173:170-177. doi:10.1007/s002039900127

Brandi M, Cerbino D, Laghetti G et al (1998) Una carta di identità per il fagiolo di Sarconi e Rotonda. L'Informatore Agrario 27:55-61

Cappuccino JG, Sherman N (2010) Microbiology, a laboratory manual. Benjamin Cummings, San Francisco, CA

Chan JWYF, Goodwin PH (1999) Differentiation of Xanthomonas campestris pv. phaseoli from Xanthomonas campestris pv. phaseoli var. fuscans by PFGE and RFLP. Eur J Plant Pathol 105:867-878. doi:10.1023/A:1008785809368

Claflin L (2003) Control of Pseudomonas syringae pathovars. In: Iacobellis NS, Collmer A, Hutcheson SW, Mansfield JW, Morris CE, Murillo J, Schaad NW, Stead DE, Surico G, Ullrich MS (eds) Pseudomonas syringae and related pathogens. Kluwer Academic, Dordrecht, pp 423-430

Coyne DP, Schuster ML (1974) Breeding and genetic studies of tolerance to several bean (Phaseolus vulgaris L.) bacterial pathogens. Euphytica 23:651-656. doi:10.1007/BF00022486

Dinelli G, Bonetti A, Minelli M et al (2006) Content of flavonols in Italian bean (Phaseolus vulgaris L.) ecotypes. Food Chem 99:105-114. doi:10.1016/j.foodchem.2005.07.028

Gilbertson RL, Maxwell DP (1992) Common bacterial blight of bean. In: Chaube HS, Kumar J, Mukhopadhyay AN, Singh US (eds) Plant diseases of international importance, vol II. Prentice Hall, Englewood Cliffs, NJ, pp 18-39

Giorgio A (2014) Studies on rhizobacterial antagonists of Phaseolus vulgaris in the biological control of plant diseases: mechanisms and metabolic aspects. $\mathrm{PhD}$ dissertation, international $\mathrm{PhD}$ in Crop System, Forestry and Environmental Sciences. Università degli Studi della Basilicata, XXVI cycle, defended in a.a. 2012/2013, promoter Iacobellis NS

Giorgio A, Bakker PAHM, Iacobellis NS (2013) Induced systemic resistance in Arabidopsis thaliana elicited by bean (Phaseolus vulgaris) rhizobacteria and their volatiles against Xanthomonas campestris pv. armoraciae. J Plant Pathol 95:S4.26

Gordon SA, Weber RP (1951) Colorimetric estimation of indole acetic acid. Plant Physiol 26:192-195

Hardoim PR, van Overbeek LS, van Elsas JD (2008) Properties of bacterial endophytes and their proposed role in plant growth. Trends Microbiol 16:463-471. doi:10.1016/j.tim.2008.07.008

Iacobellis NS, Lo Cantore P, Capasso F et al (2005) Antibacterial activity of the Cuminum cyminum L. and Carum carvi L. essential oils. J Agric Food Chem 53:57-61. doi:10.1021/ jf0487351

Kloepper JW, Leong J, Teintze M et al (1980) Pseudomonas siderophores: a mechanism explaining disease-suppressive soils. Curr Microbiol 4:317-320. doi:10.1007/BF02602840

Knowles CJ (1976) Microorganisms and cyanide. Bacteriol Rev 40:652-680

Kotan R, Cakir A, Dadasoglu F et al (2010) Antibacterial activities of essential oils and extracts of Turkish Achillea, Satureja and Thymus species against plant pathogenic bacteria. J Sci Food Agric 90:145-160. doi:10.1002/jsfa.3799

Lioi L, Piergiovanni AR, Pignone D et al (2005) Genetic diversity of some surviving on-farm Italian common bean (Phaseolus vulgaris L.) landraces. Plant Breed 124:576-581

Lo Cantore P, Iacobellis NS (2007) Characterization of strains of the varieties fuscans and non fuscans of Xanthomonas axonopodis pv. phaseoli. Plant Pathol 89(Supplement):S44

Lo Cantore P, Iacobellis NS, De Marco A et al (2004a) Antibacterial activity of Coriandrum sativum L. and Foeniculum vulgare Miller var. vulgare (Miller) essential oils. J Agric Food Chem 52:7862-7866. doi:10.1021/jf0493122

Lo Cantore P, Nigro C, Castoro V et al (2004b) Presenza e diffusione delle batteriosi in coltivazioni di "Fagiolo di Sarconi" in Basilicata. Informatore Fitopatologico 6:41-47 
Lo Cantore P, Lazzaroni S, Coraiola M et al (2006) Biological characterization of WLIP produced by Pseudomonas "reactans" NCPPB1311. Mol Plant Microbe Interact 19:1113-1120. doi:10.1094/MPMI-19-1113

Lo Cantore P, Shanmungaiah V, Iacobellis NS (2009) Antibacterial activity of essential oil components and their potential use in seed disinfection. J Agric Food Chem 57:9454-9461. doi:10.1021/jf902333g

Lo Cantore P, Figliuolo G, Iacobellis NS (2010a) Response of traditional cultivars of Fagioli di Sarconi beans to artificial inoculation with common bacterial blight agents. Phytopathol Mediterr 49:89-94. doi:10.14601/Phytopathol_Mediterr-3368

Lo Cantore P, Sisto A, Iacobellis NS (2010b) Phenotypic and genotypic characterization of common bacterial blight bean pathogens. In: Proceedings of the 12th international conference on plant pathogenic bacteria, Parc des Expositions et des Congrès de Saint-Denis, Ile de La Réunion, France, 7-11 June 2010, p 43

López R, Asensio C, Gilbertson RL (2006) Phenotypic and genetic diversity in strains of common blight bacteria (Xanthomonas campestris pv. phaseoli and X. campestris pv. phaseoli var. fuscans) in a secondary of diversity of the common bean host suggests multiple introduction events. Phytopathology 96:1204-1213. doi:10.1094/PHYTO-96-1204

Lorck H (1948) Production of hydrocyanic acid by bacteria. Physiol Plant 1:142-146

Mahuku GS, Jara C, Henriquez MA et al (2006) Genotypic characterization of the common bean bacterial blight pathogens, Xanthomonas axonopodis pv. phaseoli and Xanthomonas axonopodis pv. phaseoli var. fuscans by rep-PCR and PCR-RFLP of the ribosomal genes. J Phytopathol 154:35-44. doi:10.1111/j.1439-0434.2005.01057.x

Marquez ML, Teran H, Singh SP (2007) Selecting common bean with genes of different evolutionary origins for resistance to Xanthomonas campestris pv. phaseoli. Crop Sci 47:1367-1374. doi:10.2135/cropsci2006.12.0769

Martinez-Viveros O, Jorquera MA, Crowley DE et al (2010) Mechanisms and practical considerations involved in plant growth promotion by rhizobacteria. J Soil Sci Plant Nutr 10:293-319. doi:10.4067/S0718-95162010000100006

Masi P, Figliuolo G, Spagnoletti Zeuli PL (1999) Landraces of bean (Phaseolus vulgaris L.) collected in Basilicata, Italy. Plant Genet Resour Newsl 119:51-55

McManus PS, Stockwell VO, Sundin GW et al (2002) Antibiotic use in plant agriculture. Annu Rev Phytopathol 40:443-465. doi:10.1146/annurev.phyto.40.120301.093927

Miklas P, Coyne DP, Grafton KF et al (2003) A major QTL for common bacterial blight resistance derives from the common bean great northern landrace cultivar Montana No. 5. Euphytica 131:137-146

Miklas PN, Smith JR, Singh SP (2006) Registration of common bacterial blight resistant dark red kidney bean germplasm line USDK-CBB-15. Crop Sci 46:1005-1006. doi:10.2135/ cropsci2005.06-0110

Miklas PN, Singh SP, Terán H et al (2011) Registration of common bacterial blight resistant cranberry dry bean germplasm line USCR-CBB-20. J Plant Regist 5:98-102. doi:10.3198/ jpr2010.03.0124crg

Mkandawire ABC, Mabagala RB, Guzman P et al (2004) Genetic diversity and pathogenic variation of common blight bacteria (Xanthomonas campestris pv. phaseoli and $X$. campestris pv. phaseoli var. fuscans) suggests pathogen coevolution with the common bean. Phytopathology 94:593-603. doi:10.1094/PHYTO.2004.94.6.593

Mutlu N, Urrea CA, Miklas PN et al (2008) Registration of common bacterial blight, rust and bean common mosaic resistant great northern common bean germplasm line ABC-Wiehing. J Plant Reg 2:53-55. doi:10.3198/jpr2007.04.0197crc

Nautiyal CS (1999) An efficient microbiological growth medium for screening phosphate solubilizing microorganisms. FEMS Microbiol Lett 170:265-270. doi:10.1111/j.1574-6968.1999. tb13383.x 
Nautiyal CS, Johri JK, Singh HB (2002) Survival of the rhizosphere-competent biocontrol strain Pseudomonas fluorescens NBRI2650 in the soil and phytosphere. Can J Microbiol 48:588-601. doi:10.1139/w02-054

Ongena M, Jacques P (2008) Bacillus lipopeptides: versatile weapons for plant disease biocontrol. Trends Microbiol 16:115-125. doi:10.1016/j.tim.2007.12.009

Oosterhaven K, Poolman B, Smid EJ (1995) s-Carvone as a natural potato sprout inhibiting, fungistatic and bacteristatic compound. Ind Crop Prod 4:23-31

Piergiovanni AR, Cerbino D, Brandi M (2000) The common bean populations from Basilicata (Southern Italy). An evaluation of their variation. Genet Resour Crop Evol 47:489-495. doi:10.1023/A:1008719105895

Raaijmakers JM, Mazzola M (2012) Diversity and natural functions of antibiotics produced by beneficial and plant pathogenic bacteria. Annu Rev Phytopathol 50:403-424. doi:10.1146/ annurev-phyto-081211-172908

Rashid M, Khalil S, Ayub N et al (2004) Organic acids production and phosphate solubilization by phosphate solubilizing microorganisms (PSM) under in vitro conditions. Pak J Biol Sci 7:187-196. doi:10.3923/pjbs.2004.187.196

Reynolds T (1987) Comparative effects of alicyclic compounds and quinones on inhibition of lettuce fruit germination. Ann Bot 60:215-223

Rodrigues R, Leal NR, Pereira MG et al (1999) Combining ability of Phaseolus vulgaris L. for resistance to common bacterial blight. Genet Mol Biol 22:571-575

Saettler AW (1989) Common bacterial blight. In: Schwartz HF, Pastor-Corrales MA (eds) Bean production problems in the tropics. Centro Internacional de Agricultura Tropical, Cali, pp 261-283

Saharan BS, Nehra V (2011) Plant growth promoting rhizobacteria: a critical review. Life Sci Med Res 21:1-30

San Yu S, Zaw Ko Latt ZK, Kyaw EP et al (2011) Accumulation of ammonia in culture broth by wild-type nitrogen fixing bacterium, Stenotrophomonas maltophilia. Int J Appl Biol Pharm Technol 2:72-77

Schaad NW, Jones JB, Lacy GH (eds) (2001) Laboratory guide for identification of plant pathogenic bacteria, 3rd edn. APS, St. Paul, MN

Schaad NW, Postnikova E, Lacy GH et al (2005) Reclassification of Xanthomonas campestris pv. citri (ex Hasse 1915) Dye 1978 forms A, B/C/D, and E as X. smithii subsp. citri (ex Hasse) sp. nov. nom. rev. comb. nov., X. fuscans subsp. aurantifolii (ex Gabriel 1989) sp. nov. nom. rev. comb. nov., and X. alfalfae subsp. citrumelo (ex Riker and Jones) Gabriel et al., 1989 sp. nov. nom. rev. comb. nov.; X. campestris pv malvacearum (ex Smith 1901) Dye 1978 as $X$. smithii subsp. smithii nov. comb. nov. nom. nov.; X. campestris pv. alfalfae (ex Riker and Jones, 1935) Dye 1978 as X. alfalfae subsp. alfalfae (ex Riker et al., 1935) sp. nov. nom. rev.; and "var. fuscans" of X. campestris pv. phaseoli (ex Smith, 1987) Dye 1978 as X. fuscans subsp. fuscans sp. nov. Syst Appl Microbiol 28:494-518. doi:10.1016/j.syapm.2005.03.017

Schaad NW, Postnikova E, Lacy G et al (2006) Emended classification of xanthomonad pathogens on citrus. Syst Appl Microbiol 29:690-695. doi:10.1016/j.syapm.2005.03.017

Schachtman DP, Reid RJ, Ayling SM (1998) Phosphorus uptake by plants: from soil to cell. Plant Physiol 116:447-453. doi:10.1104/pp.116.2.447

Schwyn B, Neilands JB (1987) Universal chemical assay for the detection and determination of siderophores. Anal Biochem 160:47-56. doi:10.1016/0003-2697(87)90612-9

Seow YX, Yeo CR, Chung HL et al (2014) Plant essential oils as active antimicrobial agents. Crit Rev Food Sci Nutr 54:625-644. doi:10.1080/10408398.2011.599504

Si W, Gong J, Tsao R et al (2006) Antimicrobial activity of essential oils and structurally related synthetic food additives towards selected pathogenic and beneficial gut bacteria. J Appl Microbiol 100:296-305. doi:10.1111/j.1365-2672.2005.02789.x

Singh SP, Muñoz CG, Terán H (2001) Registration of common bacterial blight resistant dry bean germplasm VAX 1, VAX 3, and VAX 4. Crop Sci 41:275-276. doi:10.2135/cropsci2001. $411275 x$ 
FAO Statistics Division (2014) Food and agriculture organization of the United Nations. http:// faostat.fao.org. Accessed 2 Nov 2014

Tarlan B, Michaels TE, Pauls KP (2001) Mapping genetic factors affecting the reaction to Xanthomonas axonopodis pv. phaseoli in Phaseolus vulgaris L. under field conditions. Genome 44:1046-1056

Terzi V, Morcia C, Faccioli P et al (2007) In vitro antifungal activity of the tea tree (Melaleuca alternifolia) essential oil and its major components against plant pathogens. Lett Appl Microbiol 44:613-618. doi:10.1111/j.1472-765X.2007.02128.x

Tinivella F, Hirata LM, Celan MA et al (2009) Control of seed-borne pathogens on legumes by microbial and other alternative seed treatments. Eur J Plant Pathol 123:139-151. doi:10.1007/ s10658-008-9349-3

Van Loon LC (2007) Plant responses to plant growth-promoting rhizobacteria. Eur J Plant Pathol 119:243-254. doi:10.1007/s10658-007-9165-1

Vauterin L, Hoste B, Kersters K et al (1995) Reclassification of Xanthomonas. Int J Syst Bacteriol 45:472-489. doi:10.1099/00207713-45-3-472

Weise T, Kai M, Piechulla B (2013) Bacterial ammonia causes significant plant growth inhibition. PLoS One 8:e63538. doi:10.1371/journal.pone.0063538

Yoshii K, Galvez GE, Alvarez G (1978) Screening bean germplasm for tolerance to common bacterial blight caused by Xanthomonas phaseoli and the importance of pathogenic variation to varietal improvement. Plant Dis Rep 62:343-347

Zanatta ZGCN, Moura AB, Maia LC et al (2007) Bioassay for selection of biocontroller bacteria against bean common blight (Xanthomonas axonopodis pv. phaseoli). Braz J Microbiol 38:511-515. doi:10.1590/S1517-83822007000300024 